\title{
Role of airline food quality, price reasonableness, image, satisfaction, and attachment in building re-flying intention
}

\begin{abstract}
Quality of in-flight food and beverage is undoubtedly one of the most important requisites for passengers' pleasurable flight experiences in the full-service airline industry. Nonetheless, little is known about its role in forming re-flying intention. The present research successfully addressed this omission by uncovering the positive relationships among multiple quality factors of in-flight food and beverage (core, external, and delivery), price reasonableness, airline image, satisfaction, and re-flying intention in an empirical manner. Specifically, our findings verified the effectiveness of the higher-order structure of in-flight food and beverage quality that significantly enhances passengers' perceived reasonableness of price, airline image, and satisfaction in their re-flying decision-making process. Our empirical result also identified the mediating impact of price, image, and satisfaction. Moreover, the result of the metric-invariance test demonstrated the significant moderating impact of passenger attachment to in-flight food and beverage on re-flying intention formation. Implications for theory and practice are discussed.
\end{abstract}

Keyword: In-flight food and beverage; Full-service airline; Quality; Passenger; Re-flying intention 